JIPSINDO No. 1, Volume 2, Maret 2015

\title{
PENGEMBANGAN MEDIA PEMBELAJARAN IPS TERPADU BERBASIS AUDIOVISUAL
}

\author{
Supardi, \\ Anik Widiastuti, \\ Saliman
}

Pendidikan IPS Fakultas Ilmu Sosial UNY

Email : anikwidiastuti@uny.ac.id. Hp. 085213323505

\begin{abstract}
Abstrak
Penelitian ini bertujuan untuk mengembangkan media pembelajaran IPS terpadu yang berorientasi pada produk. Subjek penelitian ini adalah siswa kelas VII SMP Darul Hikmah Pakem Sleman Yogyakarta. Teknik pengumpulan data menggunakan teknik kuesioner/angket. Data yang diperoleh dari angket yang berupa data kuantitatif diolah dengan teknik analisis data kuantitatif. Pengolahan data kuantitatif dalam penelitian ini menggunakan statistik deskriptif. Hasil penelitian menunjukkan bahwa pengembangan media audio visual dalam pembelajaran IPS untuk siswa SMP kelas VII dengan tema "Antara Borobudur dan Prambanan" dinyatakan baik sehingga layak untuk digunakan dalam pembelajaran. Hal ini ditunjukkan dengan penilaian isi dan aspek kebahasaan oleh ahli materi dengan rerata skor masingmasing 3,5 dan 3,5 pada kategori "baik", aspek tampilan dan pemprograman oleh ahli media masing-masing memiliki rerata skor 3,40 dan 3,00 pada kategori "cukup". Hasil uji keterbacaan siswa terhadap media audio visual mendapatkan respon positif dari siswa yang ditunjukkan dengan skor terendah 3,0 pada kategori "cukup" dan skor tertinggi 4,3 pada kategori "sangat baik".
\end{abstract}

Kata kunci : pengembangan media, IPS Terpadu 


\begin{abstract}
This research aims to develop an integrated social studies instructional media oriented to products. The subjects research were students of class VII SMP Darul Hikmah, Sleman, Yogyakarta. The techniques data collecting use questionnaire. The data obtained from the questionnaire in the form of quantitative data processed by quantitative data analysis. Processing of quantitative data using the descriptive statistics. The results show that the development of audio-visual media in teaching of social studies to junior high school students of class VII with the theme "Between Borobudur and Prambanan" declared good so worthy to be used in learnings. Its indicate by the content and aspects of language assessment by experts of material with a mean score of the respective 3.5 and 3.5 in the category of "good", aspects of the display and programming by media experts each had a mean score of 3.40 and 3,00 in the category of "enough". Readability test results of students to audiovisual media to get positive response from students indicated by the lowest score 3.0 in the category "sufficient" and the highest score of 4.3 in the category of "very good".
\end{abstract}

Keywords: media development, social-studies integrated

\title{
Pendahuluan
}

Pesatnya perkembangan Ilmu Pengetahuan dan Teknologi (IPTEK) mempengaruhi berbagai segi kehidupan manusia, salah satunya dalam bidang pendidikan. Dunia pendidikan saat ini semakin berkembang, berbagai macam pembaharuan dilakukan agar dapat meningkatkan kualitas dan kuantitas pendidikan. Untuk meningkatkan kualitas pendidikan diperlukan berbagai terobosan, baik dalam pengembangan kurikulum, inovasi pembelajaran, dan pemenuhan sarana prasarana pendidian. Guru dituntut untuk membuat pembelajaran menjadi lebih inovatif yang mendorong siswa dapat belajar secara optimal baik didalam belajar mandiri maupun didalam pembelajaran dikelas.

Ketercapaian tujuan pembelajaran dipengaruhi oleh berbagai aspek, antara lain aspek guru, siswa, ketersediaan saranaprasarana, penggunaan sumber belajar yang variatif, penerapan 
metode pembelajaran yang tidak monoton, serta penggunaan media yang menarik. Kemajuan jaman yang diiringi oleh kecanggihan teknologi mendukung penggunaan media yang bervariasi dalam pembelajaran. Permasalahan yang sering muncul dalam pembelajaran adalah adanya keterbatasan ketrampilan guru untuk menggunakan media, keterbatasan sarana prasarana yang tersedia di sekolah, dan juga keterbatasan ketersediaan media pembelajaran itu sendiri. Pembelajaran pada dasarnya adalah proses komunikasi yang dilakukan untuk penyampaian informasi dari guru kepada siswa, oleh karena itu media pembelajaran menempati posisi penting sebagai salah satu sistem pembelajaran, termasuk dalam pembelajaran IPS. Mata pelajaran IPS merupakan mata pelajaran integrasi dari mata pelajaran Sejarah, Geografi, dan Ekonomi serta mata pelajaran ilmu sosial lainnya (Sapriya, 2009: 7).

Pendidikan IPS untuk tingkat sekolah bisa diartikan sebagai: (1) Pendidikan IPS yang menekankan pada tumbuhnya nilai-nilai kewarganegaraan, moral ideologi negara dan agama; Pendidikan IPS yang menekankan pada isi dan metode berpikir ilmuan sosial; (3) pendidikan IPS yang menekankan pada reflective inquiry; dan (4) Pendidikan IPS yang mengambil kebaikankebaikan dari butir 1, 2, 3, di atas (Muhammad Numan Somantri, 2001: 44). Groos (Sekar Purbarini Kawuryan, 2008: 24) bahwa tujuan utama pembelajaran IPS adalah untuk melatih siswa bertanggung jawab sebagai warga negara yang baik. Dalam UU No. 20 tahun 2003 tentang Sistem Pendidikan Nasional, dijelaskan bahwa IPS merupakan bahan kajian yang wajib dimuat dalam kurikulum pendidikan dasar dan menengah yang antara lain mencakup ilmu bumi, sejarah, ekonomi, kesehatan dan lain sebagainya yang dimaksudkan untuk mengembangkan 
pengetahuan, pemahaman, dan kemampuan analisis peserta didik terhadap kondisi sosial masyarakat (penjelasan pasal 37).

Ilmu Pengetahuan Sosial sebagai bahan kajian merupakan subject matter yang dapat dikemas menjadi satu atau beberapa mata pelajaran atau diintegrasikan dengan bahan kajian lain sesuai dengan kebutuhan pendidikan. IPS sebagai salah satu mata pelajaran yang membahas dinamika permasalahan sosial memerlukan dukungan media yang dapat mengungkap aspekaspek tersebut. Pembelajaran yang didukung media yang menarik dapat meningkatkan ketertarikan siswa dan dapat memperlancar ketercapaian tujuan pembelajaran IPS di SMP. Sayangnya, guruguru IPS SMP masih banyak yang tidak menggunakan variasi media dalam mengajar, yang penting menyampaikan materi. Media yang paling sering dipakai oleh guru adalah LKS. Padahal pembahasan materi IPS yang banyak konsep-konsepnya dan bersifat abstrak membutuhkan visualisasi untuk mempermudah siswa memahami materi yang disampaikan guru. Salah satu alternatif yang dapat digunakan untuk mempermudah penyampaian materi adalah penggunaan media pembelajaran yang tepat.

\section{Media Pembelajaran}

Menurut Haryanto (2012: 1) media merupakan segala sesuatu yang dapat dipergunakan untuk merangsang pikiran, perasaan, perhatian dan kemampuan atau ketrampilan pebelajar, sehingga dapat mendorong terjadinya proses belajar. Dalam pembelajaran IPS diperlukan media pembelajaran IPS. Media pembelajaran IPS adalah perantara dalam menyampaikan pembelajaran IPS yang dapat berupa buku, film, video dan sebagainya. Anderson (Mawardi, 2012: 1) mengelompokkan media menjadi 10 golongan sebagai berikut: 


\begin{tabular}{|c|c|c|}
\hline No & $\begin{array}{c}\text { Golongan } \\
\text { Media }\end{array}$ & Contoh dalam Pembelajaran \\
\hline $\mathrm{I}$ & Audio & Kaset audio, siaran radio, $\mathrm{CD}$, telepon \\
\hline II & Cetak & $\begin{array}{l}\text { Buku pelajaran, modul, brosur, leaflet, } \\
\text { gambar }\end{array}$ \\
\hline III & Audio-cetak & $\begin{array}{l}\text { Kaset audio yang dilengkapi bahan } \\
\text { tertulis }\end{array}$ \\
\hline IV & $\begin{array}{l}\text { Proyeksi } \\
\text { visual diam }\end{array}$ & $\begin{array}{l}\text { Overhead transparansi (OHT), Film } \\
\text { bingkai (slide) }\end{array}$ \\
\hline $\mathrm{V}$ & $\begin{array}{l}\text { Proyeksi } \\
\text { Audio visual } \\
\text { diam }\end{array}$ & Film bingkai (slide) bersuara \\
\hline $\mathrm{VI}$ & Visual gerak & Film bisu \\
\hline VII & $\begin{array}{l}\text { Audio Visual } \\
\text { gerak, }\end{array}$ & film gerak bersuara, video/ $V C D$, televisi \\
\hline VIII & Obyek fisik & Benda nyata, model, specimen \\
\hline IX & $\begin{array}{l}\text { Manusia dan } \\
\text { lingkungan }\end{array}$ & Guru, Pustakawan, Laboran \\
\hline $\mathrm{X}$ & Komputer & $\begin{array}{l}\text { CAI (Computer Assisted } \\
\text { Instructional=Pembelajaran berbantuan } \\
\text { komputer), CMI (Computer Managed } \\
\text { Instructional). }\end{array}$ \\
\hline
\end{tabular}

Proses pembelajaran saat ini banyak mengalami perubahan dari metode ceramah dengan media papan tulis dan buku menjadi lebih interaktif dengan media pembelajaran yang beragam. Pemanfaatan media pendidikan diharapkan mampu mencapai tujuan pendidikan dan peningkatan kualitas pembelajaran. Ada beberapa jenis media pembelajaran yang biasa digunakan dalam proses pembelajaran.

Penggunaan media diharapkan dapat menarik perhatian siswa sehingga siswa memusatkan pikirannya dan terdorong untuk terlibat dalam kegiatan pembelajaran IPS di kelas. Cakupan materi IPS yang sangat luas membuat guru mengejar ketuntasan penyampaian materi, yang dampaknya pembelajaran IPS di SMP hanya sekedar transfer ilmu dari guru kepada siswa tanpa memperhatikan kebermaknaan pembelajaran tersebut bagi diri 
siswa dan kehidupannya. Akhirnya materi yang diterima tidak bertahan lama dalam ingatan siswa.

Banyak guru yang mengalami kesulitan untuk menuntaskan penyampaian materi, padahal sebenarnya materi dapat divisualisasi menggunakan suatu media. Terdapat berbagai jenis media pembelajaran yang dapat digunakan oleh guru. Menurut Rudy Brets (Muwardi, 2012: 1), ada 7 (tujuh) klasifikasi media, yaitu :

1. Media audio visual gerak, seperti : Film bersuara, film pada televisi, Televisi dan animasi.

2. Media audio visual diam, seperti: slide.

3. Audio semi gerak, seperti: tulisan bergerak bersuara.

4. Media visual bergerak, seperti: film bisu.

5. Media visual diam, seperti: slide bisu, halaman cetak, foto.

6. Media audio, seperti: radio, telephon, pita audio.

7. Media cetak, seperti: buku, modul.

Terdapat berbagai jenis media seperti yang telah diungkapkan di atas, akan tetapi media pembelajaran IPS yang tersedia jumlahnya sangat terbatas. Oleh karena itu, dibutuhkan pengembangan media pembelajaran IPS. Pengembangan media pembelajaran yang akan dilakukan berupa media pembelajaran IPS berbasis audiovisual.

Menurut Tim Pengembangan MKDP Kurikulum dan Pembelajaran (2009: 150), media audio - visual adalah media dengan kombinasi audio dan visual, atau biasa disebut media pandang dan dengar. Dengan menggunakan media ini, penyajian bahan ajar kepada para siswa akan semakin lengkap dan optimal. Selain itu dengan media ini, dalam batas - batas tertentu dapat menggantikan peran tugas guru. Dalam hal ini, guru tidak selalu berperan sebagai penyaji materi (teacher) tetapi karena penyajian 
materi bisa digantikan oleh media, maka peran guru bisa beralih menjadi fasilitator belajar, yaitu memberikan kemudahan bagi para siswa untuk belajar.

\section{Metode Penelitian}

Penelitian ini merupakan penelitian pengembangan atau dikenal dengan istilah R\&D (Research and Development), yang bertujuan untuk mengembangkan bahan ajar IPS terpadu yang berorientasi pada produk. Pengumpulan data menggunakan teknik kuesioner/angket. Data yang diperoleh dari angket yang berupa data kuantitatif diolah dengan teknik analisis data kuantitatif. Pengolahan data kuantitatif dalam penelitian ini menggunakan statistik deskriptif. Tahap pengembangan yang dilakukan melalui langkah seperti yang digambarkan pada skema berikut, gambar 1 :

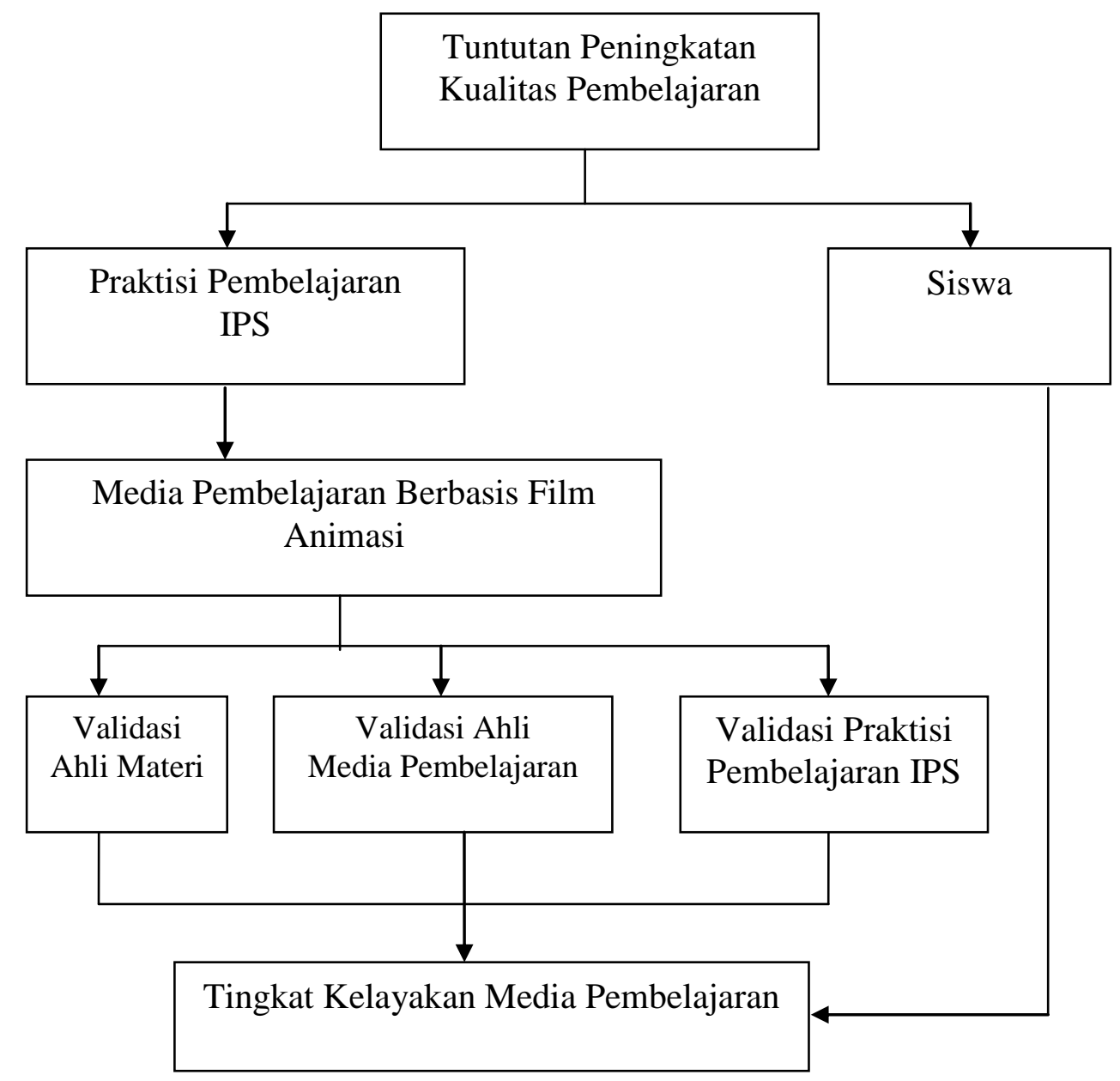




\section{Hasil Penelitian}

Produk yang dikembangkan dalam penelitian ini adalah media audio visual dengan tema "Antara Borobudur dan Prambanan" yang di dalamnya merupakan materi keterpaduan dalam pembelajaran IPS. Pengumpulan informasi melalui studi pustaka dan studi lapangan diantaranya tentang tingkat ketertarikan siswa terhadap media audio visual dalam pembelajaran, kondisi pembelajaran di sekolah, keadaan sekolah, potensi yang dimiliki sekolah, dan sebagainya. Pada tahap ini juga dilakukan analisis kurikulum yaitu dengan mengidentifikasi kompetensi dasar yang terdapat dalam Standar Isi IPS SMP pada kurikulum 2006.

Hasil analisis kurikulum adalah pemetaan materi yang dikembangkan dalam media audio visual sebagai berikut.

Peta Materi

Antara Borobudur dan Prambanan

\begin{tabular}{|l|l|l|}
\hline $\begin{array}{c}\text { Konsep } \\
\text { IPS }\end{array}$ & \multicolumn{1}{|c|}{ KD } & \multicolumn{1}{c|}{ Materi } \\
\hline Geografi & $\begin{array}{l}\text { 1.1 Mendeskripsikan } \\
\text { keragaman bentuk } \\
\text { muka bumi, proses } \\
\text { pembentukan, dan } \\
\text { dampaknya terhadap } \\
\text { kehidupan }\end{array}$ & $\begin{array}{l}\text { Letak Candi Borobudur dan } \\
\text { Prambanan } \\
\text { Proses pembentukan } \\
\text { Permukaan Bumi (gunung api, } \\
\text { sungai, laut, dampaknya } \\
\text { terhadap kondisi tanah di } \\
\text { sekitar gunung Merapi Merbabu } \\
\text { dan sekitarnya) }\end{array}$ \\
\hline Sejarah & $\begin{array}{l}\text { 5.1 Mendeskripsikan } \\
\text { perkembangan } \\
\text { masyarakat, } \\
\text { kebudayaan dan } \\
\text { pemerintahan pada } \\
\text { masa Hindu-Budha } \\
\text { serta peninggalan- } \\
\text { peninggalannya }\end{array}$ & $\begin{array}{l}\text { Borobudur dan Prambanan } \\
\text { sebagai bukti kerajaan Mataram } \\
\text { Borobudur dan Prambanan } \\
\text { sebagai peninggalan Hindu } \\
\text { Buddha } \\
\text { Sejarah pembangunan Candi } \\
\text { Borobudur dan Prambanan } \\
\text { Candi-candi di sekitar } \\
\text { Borobudur dan Prambanan } \\
\text { Perbedaan Candi Hindu dan } \\
\text { Buddha } \\
\text { Makna Borobudur dan }\end{array}$ \\
\hline
\end{tabular}




\begin{tabular}{|c|c|c|}
\hline & & Prambanan \\
\hline Sosiologi & $\begin{array}{l}\text { 2.3. Mengidentifikasi } \\
\text { bentuk-bentuk } \\
\text { interaksi sosial } \\
2.4 \text { Menguraikan } \\
\text { proses interaksi } \\
\text { sosial }\end{array}$ & $\begin{array}{l}\text { Interaksi sosial di lingkungan } \\
\text { Candi Borobudur dan } \\
\text { prambanan } \\
\text { Dampak interaksi sosial di } \\
\text { lingkungan Candi Borobudur } \\
\text { dan prambanan }\end{array}$ \\
\hline Ekonomi & $\begin{array}{l}\text { 6.4 Mengungkapkan } \\
\text { gagasan kreatif } \\
\text { dalam tindakan } \\
\text { ekonomi untuk } \\
\text { mencapai } \\
\text { kemandirian dan } \\
\text { kesejahteraan }\end{array}$ & $\begin{array}{l}\text { Gagasan kreatif dalam kegiatan } \\
\text { ekonomi } \\
\text { Bentuk-bentuk gagasan kreatif } \\
\text { dalam kegiatan ekonomi }\end{array}$ \\
\hline
\end{tabular}

Untuk memudahkan proses pengembangan aplikasi media audio visual pada tahap pengembangan produk, maka pada tahap perencanaan pengembangan ini dibuat diagram alir (flowchart) dan storyboard. Dalam pengembangan produk, dilakukan beberapa tahap diantaranya :

1. Pembuatan pemetaan materi yang akan dikembangkan Pemetaan materi dilakukan untuk mengidentifikasi materi yang dapat dipadukan dalam tema "Antara Borobudur dan Prambanan". Kegiatan ini dilakukan dengan mengidentifikasi standar kompetensi dan kompetensi dasar mata pelajaran IPS yang berkaitan dengan tema. Setelah melakukan identifikasi materi, kemudian membuat jejaring tema dengan tujuan memperoleh pilihan materi yang akan dikembangkan di dalam media. Selanjutnya menyusun materi yang sistematis dan siap dikemas dalam sebuah cerita.

2. Menyusun sinopsis

Untuk memudahkan penyusunan cerita, langkah yang dilakukan pada tahap awal adalah penyusunan sinopsis. Kegiatan ini dilakukan untuk menjadi panduan utama dalam langkah berikutnya. Sinopsis berisi cerita singkat di dalam film yang akan dikerjakan. 
3. Menyusun cerita

Langkah berikutnya adalah menyusun cerita lengkap yang berisi materi utama di dalam film. Penyusunan cerita didasarkan pada jejaring tema yang telah dilakukan pada langkah pertama.

4. Menyusun story board

Setelah cerita selesai disusun, lalu dilanjutkan dengan pembuatan story board. Story board yang disusun merupakan kegiatan setiap adegan yang akan diambil dalam pembuatan film. Dalam story board sudah disusun gambar apa yang akan diambil, bagaimana tayangan yang akan diinginkan, dan isi suara apa yang akan dimasukkan. Penyusunan story board dibagi dalam beberapa panel untuk memudahkan pengambilan gambar. Dengan pembuatan story board maka pengambilan gambar dapat dilakukan tidak urut, karena cerita dapat dipotong-potong dan akan diurutkan pada saat editing.

5. Pengambilan gambar

Pengambilan gambar didasarkan pada storyboard yang telah disusun, langsung ke lokasi dan sebagian dibuatkan animasi.

6. Editing dan pengisian suara

Setelah pengambilan gambar selesai, langkah selanjutnya adalah editing gambar dan pengisian suara. Kegiatan ini dilakukan di dalam laboratorium. Kegiatan dilakukan sampai film siap disajikan.

7. Validasi ahli materi dan ahli media

Kegiatan validasi materi dilakukan oleh ahli materi IPS sedangkan validasi ahli media dilakukan oleh ahli media pembelajaran. 
8. Revisi

Hasil masukan ahli media dan ahli materi digunakan untuk memperbaiki film yang telah dibuat.

9. Uji coba

Uji coba dilakukan di SMP Darul Hikmah Pakem Sleman Yogyakarta.

a. Data Validasi Ahli Materi

Validasi ahli materi dilakukan dosen Jurusan Pendidikan IPS FIS UNY. Penilaian produk $\mathrm{R}$ dinilai dari aspek pembelajaran dan aspek materi. Berikut adalah data hasil evaluasi ahli materi.

1) Aspek Pembelajaran

Tabel 1. Evaluasi ahli materi pada aspek pembelajaran

\begin{tabular}{|c|l|c|}
\hline No. & \multicolumn{1}{|c|}{ Indikator } & Skor \\
\hline 1. & $\begin{array}{l}\text { Kesesuaian materi dengan kompetensi } \\
\text { dasar }\end{array}$ & 4 \\
\hline 2. & $\begin{array}{l}\text { Ketepatan memilih materi yang } \\
\text { dimediakan }\end{array}$ & 4 \\
\hline 3. & Materi yang dipadukan & 3 \\
\hline 4. & Kejelasan petunjuk belajar & 3 \\
\hline 5. & Kemudahan memilih menu belajar & 4 \\
\hline 6. & Tingkat interaksi siswa dengan media & 3 \\
\hline 7. & $\begin{array}{l}\text { Ketepatan memilih bahasa dalam } \\
\text { uraian }\end{array}$ & 3 \\
\hline 8. & Pemberian motivasi belajar & 4 \\
\hline Total penilaian & 30 \\
\hline \multicolumn{2}{|l|}{ Rata-rata } \\
\hline
\end{tabular}

2) Aspek isi materi

Tabel 2. Evaluasi ahli materi pada aspek isi materi

\begin{tabular}{|c|l|c|}
\hline No. & Indikator & Skor \\
\hline 1. & Kebenaran Konsep & 4 \\
\hline 2. & $\begin{array}{l}\text { Kecukupan materi untuk mencapai } \\
\text { tujuan }\end{array}$ & 3 \\
\hline 3. & Kejelasan materi & 3 \\
\hline 4. & Sistematika penyajian materi & 4 \\
\hline 5. & Urutan materi & 4 \\
\hline 6. & Kelayakan contoh yang disajikan & 4 \\
\hline
\end{tabular}




\begin{tabular}{|c|l|c|}
\hline 7. & Kelugasan bahasa & 4 \\
\hline 8. & Kejelasan Bahasa & 4 \\
\hline 9. & $\begin{array}{l}\text { Ketepatan animasi untuk } \\
\text { menjelaskan materi }\end{array}$ & 3 \\
\hline 10. & $\begin{array}{l}\text { Ketepatan gambar menjelaskan } \\
\text { materi }\end{array}$ & 3 \\
\hline \multicolumn{2}{|l|}{ Total Penilaian } & 35 \\
\hline \multicolumn{2}{|l|}{ Rata-rata } & 3.5 \\
\hline
\end{tabular}

Jumlah skor rata-rata penilaian ahli materi pada aspek pembelajaran dan aspek isi materi di dapat dari hasil perhitungan tabel di bawah ini:

Tabel 3. Data Penilaian Ahli Materi Aspek Pembelajaran dan Aspek Isi Materi

\begin{tabular}{|c|c|c|c|}
\hline No & Aspek Penilaian & Skor & Skor rata-rata \\
\hline 1 & Pembelajaran & 30 & 3,5 \\
\hline 2 & Isi materi & 39 & 3,5 \\
\hline \multicolumn{3}{|c|}{ Jumlah Skor rata-rata } & 7 \\
\hline
\end{tabular}

b. Data Validasi Ahli Media

Validasi ahli media dilakukan oleh dosen Jurusan Pendidikan IPS Fakultas Ilmu Sosial, Universitas Negeri Yogyakarta yang berkompeten dibidang media pembelajaran. Berikut adalah data hasil evaluasi ahli media.

1) Aspek Tampilan

Hasil penilaian pada aspek tampilan adalah sebagai berikut:

Tabel 4. Evaluasi Ahli Media pada aspek tampilan

\begin{tabular}{|c|l|c|}
\hline No & \multicolumn{1}{|c|}{ Indikator } & Skor \\
\hline 1 & Kesesuaian warna tulisan & 3 \\
\hline 2 & Ketepatan pemilihan jenis huruf & 3 \\
\hline 3 & Ketepatan pemilihan ukuran huruf & 4 \\
\hline 4 & Ketepatan ukuran gambar video & 3 \\
\hline 5 & Kejelasan warna gambar video & 3 \\
\hline 6 & $\begin{array}{l}\text { Ketepatan pemilihan warna pada } \\
\text { background }\end{array}$ & 3 \\
\hline 7 & $\begin{array}{l}\text { Keserasian warna tulisan dengan } \\
\text { warna background }\end{array}$ & 3 \\
\hline 8 & Ketepatan pemilihan backsound & 4 \\
\hline 9 & Kejelasan audio & 3 \\
\hline
\end{tabular}




\begin{tabular}{|l|l|c|}
\hline 10 & Kejelasan animasi & 3 \\
\hline 11 & Kemenarikan animasi & 4 \\
\hline 12 & Kejelasan objek animasi & 4 \\
\hline 13 & Keserasian objek animasi & 4 \\
\hline 14 & Variasi transisi setiap gambar video & 3 \\
\hline \multicolumn{2}{|l|}{ Total penilaian } & 47 \\
\hline \multicolumn{2}{|l|}{ Rata-rata } & 3.40 \\
\hline
\end{tabular}

2) Aspek Pemrograman

Tabel 5. Evaluasi Ahli Media pada Aspek Pemrograman

\begin{tabular}{|c|l|c|}
\hline No & \multicolumn{1}{|c|}{ Indikator } & Skor \\
\hline 1 & Dapat menarik siswa & 3 \\
\hline 2 & $\begin{array}{l}\text { Kemudahan berinteraksi dengan } \\
\text { media }\end{array}$ & 3 \\
\hline 3 & $\begin{array}{l}\text { Kejelasan petunjuk penggunaan } \\
\text { media }\end{array}$ & 2 \\
\hline 4 & Kemudahan mengoperasikan video & 3 \\
\hline 5 & Kemudahan mengatur video & 3 \\
\hline 6 & Ketepatan animasi & 4 \\
\hline 7 & Pengaturan animasi & 3 \\
\hline 8 & Efisiensi penggunaan video & 3 \\
\hline 9 & $\begin{array}{l}\text { Rapih,teratur,tidak tercampur gambar } \\
\text { yang tidak perlu }\end{array}$ & 27 \\
\hline Total Penilaian & 3.0 \\
\hline \multicolumn{2}{|l|}{ Rata-rata } & \\
\hline
\end{tabular}

Tabel 6 . Data Penilaian Ahli Media dari Aspek Tampilan dan Aspek Pemrograman

\begin{tabular}{|c|c|c|c|}
\hline No & Aspek Penilaian & Skor & Skor rata-rata \\
\hline 1 & Tampilan & 48 & 3,40 \\
\hline 2 & Pemrograman & 27 & 3,0 \\
\hline \multicolumn{2}{|c|}{ Jumlah Skor rata-rata } & 6,40 \\
\hline
\end{tabular}

c. Data penilaian kelayakan media oleh Guru IPS

Penilaian oleh guru difokuskan pada aspek pembelajaran, aspek isi dan aspek tampilan. Guru yang menilai kelayakan media video pembelajaran ini adalah Ibu Enung Hasanah, M.Pd, guru IPS SMP Darul Hikmah Pakem Sleman Yogyakarta, Penilaian dari guru digunakan untuk mengetahui relevan atau tidaknya media video pembelajaran terhadap materi dan yang selama ini digunakan. Data yang digunakan diperoleh dari angket skala likert yang di isi oleh guru. Data yang berupa 
angka, skor dan saran digunakan untuk memperbaiki kekurangan produk media video pembelajaran.

1) Aspek Pembelajaran

Adapun untuk hasil penilaian pada aspek pembelajaran adalah sebagai berikut:

Tabel 7. Evaluasi Guru pada aspek pembelajaran

\begin{tabular}{|c|l|c|}
\hline No & \multicolumn{1}{|c|}{ Indikator } & Skor \\
\hline 1 & Materi mudah dipelajari & 4 \\
\hline 2 & Materi menantang dan menarik & 4 \\
\hline 3 & $\begin{array}{l}\text { Materi bermanfaat untuk kehidupan } \\
\text { sehari-sehari }\end{array}$ & 5 \\
\hline 4 & Kejelasan petunjek belajar & 4 \\
\hline 5 & Umpan balik terhadap jawaban siswa & 3 \\
\hline 6 & Kemudahan memilih menu belajar & 4 \\
\hline 7 & $\begin{array}{l}\text { Dengan media ini belajar lebih } \\
\text { menyenangkan }\end{array}$ & 5 \\
\hline 8 & Media membantu belajar & 4 \\
\hline \multicolumn{2}{|c|}{ Total penilaian } & 33 \\
\hline \multicolumn{2}{|l|}{ Rata-rata } \\
\hline
\end{tabular}

2) Aspek isi

Adapun untuk penilaian pada aspek isi adalah sebagai berikut:

Tabel 8. evaluasi Guru pada aspek isi

\begin{tabular}{|c|l|c|}
\hline No & \multicolumn{1}{|c|}{ Indikator } & Skor \\
\hline 1 & Kejelasan materi & 4 \\
\hline 2 & Kelugasan bahasa & 4 \\
\hline 3 & Kejelasan bahasa & 3 \\
\hline 4 & Animasi untuk memperjelas materi & 4 \\
\hline 5 & Gambar untuk memperjelas materi & 5 \\
\hline 6 & Video untuk memperjelas materi & 4 \\
\hline \multicolumn{2}{|l|}{ Total penilaian } & 24 \\
\hline \multicolumn{2}{|l|}{ Rata-rata } & 4 \\
\hline
\end{tabular}

3) Aspek Tampilan

Adapun untuk penilaian pada aspek tampilan adalah sebagai berikut: 
Tabel 9. Evaluasi Guru pada aspek tampilan

\begin{tabular}{|c|l|c|}
\hline No & \multicolumn{1}{|c|}{ Indikator } & Skor \\
\hline 1 & Tulisan terbaca dengan jelas & 5 \\
\hline 2 & $\begin{array}{l}\text { Keserasian warna dengan } \\
\text { background }\end{array}$ & 4 \\
\hline 3 & Kemudahan mengoperasikan video & 4 \\
\hline 4 & Kejelasan petunjuk penggunaan & 3 \\
\hline 5 & Suara music pendukung & 3 \\
\hline 6 & Audio narasi terdengar dengan jelas & 4 \\
\hline 7 & Kejelasan warna animasi & 5 \\
\hline 8 & Ketepatan ukuran huruf & 4 \\
\hline 9 & Kejelasan warna gambar video & 5 \\
\hline 10 & Ketepatan warna gambar video & 4 \\
\hline 11 & Kemenarikan animasi & 4 \\
\hline 12 & Kemenarikan video & 5 \\
\hline Jumlah & 4.1 \\
\hline \multicolumn{2}{|l|}{ Rata-rata } & 50 \\
\hline
\end{tabular}

Tabel 10. Data Hasil Penilaian Dari Guru Terhadap Aspek Pembelajaran, Isi/Materi, Tampilan.

\begin{tabular}{|c|c|c|c|}
\hline No & Aspek Penilaian & Skor & $\begin{array}{c}\text { Skor Rata- } \\
\text { rata }\end{array}$ \\
\hline 1 & Pembelajaran & 33 & 4,1 \\
\hline 2 & Isi/materi & 24 & 4 \\
\hline 3 & Tampilan & 50 & 4,1 \\
\hline \multicolumn{2}{|c|}{ Jumlah skor rata-rata } & 12,2 \\
\hline
\end{tabular}

1. Data Uji Coba Lapangan (Field Class)

Tahapan uji coba kelas dilakukan di SMP Darul Hikmah Pakem Sleman Yogyakarta. Uji coba dilaksanakan pada Tanggal 3 November 2013 dengan subjek uji coba kelas VII dengan jumlah 34 siswa. Berikut adalah hasil uji coba lapangan terhadap 34 responden.

a) Aspek Pembelajaran

Pada aspek pembelajaran terdapat beberapa evaluasi yakni pada teks yang ukurannya terlalu kecil dan suara narasi yang kurang jelas, agar siswa lebih bisa memahami lagi materi yang ada pada media. Adapun untuk hasil 
penilaian pada aspek pembelajaran adalah sebagai berikut:

Tabel 11. Data hasil uji coba siswa pada aspek pembelajaran

\begin{tabular}{|c|l|c|c|}
\hline No & Indikator & Skor & Rata-rata \\
\hline 1. & Materi mudah dipelajari & 130 & 3.82 \\
\hline 2. & $\begin{array}{l}\text { Materi } \\
\text { menantang/menarik }\end{array}$ & 124 & 3.64 \\
\hline 3. & $\begin{array}{l}\text { Materi bermanfaat } \\
\text { untuk kehidupan } \\
\text { sehari-hari }\end{array}$ & 153 & 4.5 \\
\hline 4. & $\begin{array}{l}\text { Kejelasan petunjuk } \\
\text { belajar }\end{array}$ & 130 & 3.82 \\
\hline 5. & $\begin{array}{l}\text { Umpan balik terhadap } \\
\text { jawaban }\end{array}$ & 127 & 3.38 \\
\hline 6. & $\begin{array}{l}\text { Kemudahan memilih } \\
\text { menu belajar }\end{array}$ & 142 & 4.1 \\
\hline 7. & $\begin{array}{l}\text { Dengan media ini } \\
\text { belajar lebih } \\
\text { menyenangkan }\end{array}$ & 147 & 4.32 \\
\hline 8. & $\begin{array}{l}\text { Median membantu } \\
\text { belajar }\end{array}$ & 1068 & 3.92 \\
\hline & \multicolumn{1}{c}{ Jumlah } & \\
\hline
\end{tabular}

b) Aspek Tampilan

Adapun penilaian untuk aspek isi adalah sebagai berikut:

Tabel 12. Data hasil uji coba siswa pada aspek tampilan

\begin{tabular}{|c|l|c|c|}
\hline No & \multicolumn{1}{|c|}{ Indikator } & Skor & Rata-rata \\
\hline 1. & $\begin{array}{l}\text { Tulisan terbaca dengan } \\
\text { jelas }\end{array}$ & 123 & 3.64 \\
\hline 2 & $\begin{array}{l}\text { Keserasian warna } \\
\text { dengan background }\end{array}$ & 117 & 3.44 \\
\hline 3 & $\begin{array}{l}\text { Kemudahan } \\
\text { mengoperasikan video }\end{array}$ & 124 & 3.64 \\
\hline 4 & $\begin{array}{l}\text { Kejelasan petunjuk } \\
\text { penggunaan }\end{array}$ & 129 & 3.79 \\
\hline 5 & $\begin{array}{l}\text { Suara musik } \\
\text { pendukung }\end{array}$ & 127 & 3.73 \\
\hline 6 & $\begin{array}{l}\text { Audio narasi terdengar } \\
\text { dengan jelas }\end{array}$ & 125 & 3.67 \\
\hline 7 & Kejelasan warna & 118 & 3.47 \\
\hline
\end{tabular}




\begin{tabular}{|c|c|c|c|}
\hline & animasi & & \\
\hline 8 & $\begin{array}{l}\text { Ketepatan ukuran } \\
\text { huruf }\end{array}$ & 130 & 3.82 \\
\hline 9 & $\begin{array}{l}\text { Kejelasan warna } \\
\text { gambar video }\end{array}$ & 120 & 3.52 \\
\hline 10 & $\begin{array}{l}\text { Ketepatan warna } \\
\text { gambar video }\end{array}$ & 114 & 3.35 \\
\hline 11 & Kemenarikan animasi & 124 & 3.64 \\
\hline 12 & Kemenarikan video & 128 & 3.76 \\
\hline \multicolumn{2}{|c|}{ Jumlah } & 1479 & 3.62 \\
\hline
\end{tabular}

c) Aspek isi

Tabel 13. Hasil uji coba siswa pada aspek isi

\begin{tabular}{|c|c|c|c|}
\hline No & Indikator & Skor & Rara-rata \\
\hline 1 & Kejelasan materi & 125 & 3,67 \\
\hline 2 & Kelugasan bahasa & 124 & 3.64 \\
\hline 3 & Kejelasan bahasa & 123 & 3.61 \\
\hline 4 & $\begin{array}{l}\text { Animasi untuk } \\
\text { memperjelas materi }\end{array}$ & 121 & 3.55 \\
\hline 5 & $\begin{array}{l}\text { Gambar untuk } \\
\text { memperjelas materi }\end{array}$ & 120 & 3.52 \\
\hline 6 & $\begin{array}{l}\text { Video untuk } \\
\text { memperjelas materi }\end{array}$ & 126 & 3.7 \\
\hline \multicolumn{2}{|r|}{ Jumlah } & 739 & 3.62 \\
\hline
\end{tabular}

Tabel 14. Kelayakan Media Pembelajaran IPS Interaktif berdasarkan Respon Siswa

\begin{tabular}{|c|c|c|c|}
\hline No & Aspek Penilaian & $\sum$ Skor & $\begin{array}{c}\text { Skor Rata- } \\
\text { rata }\end{array}$ \\
\hline 1 & Pembelajaran & 1068 & 3,92 \\
\hline 2 & Isi/materi & 739 & 3,62 \\
\hline 4 & Tampilan & 1479 & 3,62 \\
\hline \multicolumn{2}{|c|}{ Jumlah skor rata-rata } & 11,16 \\
\hline
\end{tabular}

\section{Pembahasan}

Proses pembuatan media audio visual dengan tema "Antara Borobudur dan Prambanan" telah dilakukan sesuai prosedur penyusunan media audio visual. Langkah-langkah tersebut meliputi; pemetaan materi, penyusunan sinopsis, penyusunan cerita, pembuatan sinopsis, pengambilan gambar, editing, validasi, 
revisi, dan uji coba. Kegiatan tersebut merupakan langkahlangkah sistematis dalam penyusunan media audio visual.

Dalam proses pembuatan media audio visual, terdapat beberapa hambatan misalnya waktu yang cukup singkat untuk proses pembuatan film. Untuk menghasilkan film yang lebih baik, idealnya diperlukan 9 bulan efektif proses perencanaan sampai dengan uji coba di lapangan, kemudian melakukan revisi lagi. Keterbatasan dalam penelitian ini adalah hanya sampai pada tahap uji coba. Apabila dikembangkan sebenarnya dapat dilanjutkan pada tahap revisi dan uji coba diperluas.

Pada penilaian awal ahli media dan ahli materi, terdapat beberapa masukan dari kedua validator. Beberapa masukan yang berkaitan dengan ahli materi adalah penyederhanaan materi dan penyusunan konsep yang lebih mudah difahami siswa SMP. Sedangkan ahli media menekankan pada penggunaan suara dubbing dengan intonasi lebih lambat sehingga dapat diterima siswa dengan keragaman cara berfikir. Setelah beberapa masukan ahli diterima, kemudian dilakukan revisi produk yang dikembangkan, sehingga menghasilkan produk akhir yang kemudian dinilaikan kembali.

Untuk menentukan kelayakan secara umum media yang dikembangkan, perlu dilihat bagaimana hasil secara umum kelayakan media tersebut dari berbagai sudut penilaian. Untuk itu dapat dilihat pada rekapitulasi penilaian kelayakan sebagai berikut:

Tabel 15. Rerata Penilaian dari berbagai unsur

\begin{tabular}{|l|l|l|c|}
\hline No & \multicolumn{1}{|c|}{ Penilai } & \multicolumn{1}{|c|}{ Aspek Penilaian } & $\begin{array}{c}\text { Skor rata- } \\
\text { rata }\end{array}$ \\
\hline 1. & Ahli Materi & Pembelajaran & 3,5 \\
\hline 2. & Ahli Materi & Isi materi & 3,5 \\
\hline 3. & Ahli Media & Tampilan & 3,40 \\
\hline 4. & Ahli Media & Pemrograman & 3,0 \\
\hline
\end{tabular}




\begin{tabular}{|l|l|l|c|}
\hline 5. & Guru IPS & Pembelajaran & 4,1 \\
\hline 6. & Guru IPS & Isi/materi & 4 \\
\hline 7. & Guru IPS & Tampilan & 4,1 \\
\hline 8. & Siswa & Pembelajaran & 3,92 \\
\hline 9. & Siswa & Isi/materi & 3,62 \\
\hline 10. & Siswa & Tampilan & 3,62 \\
\hline & Rerata & & 3,676 \\
\hline
\end{tabular}

Berdasarkan pada tabulasi data di atas, dapat disimpulkan bahwa media audio visual yang telah dibuat sangat membantu guru dan siswa dalam pembelajaran IPS. Validasi yang dilakukan oleh ahli materi dan ahli media sesuai dengan respon guru dan siswa dalam tahap uji coba produk yang telah dikembangkan. Apabila dicermati, rerata penilaian guru dan siswa terhadap produk yang dikembangkan lebih tinggi daripada rerata penilaian ahli materi dan ahli media. Fakta ini dapat dijadkan salah satu bukti bahwa guru dan siswa sangat tertarik pada produk yang dikembangkan.

\section{Simpulan}

Berdasarkan hasil analisis data pada penelitian pengembangan ini, dapat disimpulkan sebagai berikut:

1. Hasil dari pengembangan media audio visual dalam pembelajaran IPS untuk siswa SMP kelas VII dengan tema "Antara Borobudur dan Prambanan" dinyatakan baik sehingga layak untuk digunakan dalam pembelajaran. Hal ini ditunjukkan dengan penilaian isi dan aspek kebahasaan oleh ahli materi dengan rerata skor masing-masing 3,5 dan 3,5 pada kategori "baik", aspek tampilan dan pemrograman oleh ahli media masing-masing memiliki rerata skor 3,40 dan 3,00 pada kategori "cukup".

2. Berdasarkan hasil uji keterbacaan siswa terhadap media audio visual dengan tema "Antara Borobudur dan Prambanan" dalam pembelajaran IPS di SMP, produk hasil pengembangan 
mendapatkan respon positif dari siswa yang ditunjukkan dengan skor terencah 3,0 pada kategori "cukup" dan skor tertinggi 4,3 pada kategori "sangat baik".

3. Hasil pengembangan media audio visual dengan tema "Antara Borobudur dan Prambanan" dalam pembelajaran IPS di SMP secara keseluruhan dinyatakan layak digunakan. Hal ini ditunjukkan dari hasil penilaian ahli materi dan ahli media dengan kriteria penilaian "baik" dengan rata-rata penilaian 4,15 dan 3,46 .

4. Hasil pengembangan media audio visual dengan tema "Antara Borobudur dan Prambanan" dalam pembelajaran IPS di SMP berdasarkan uji keterbacaan siswa secara keseluruhan dikatakan layak digunakan dengan kategori "baik". Berdasarkan uji keterbacaan siswa secara keseluruhan dikatakan layak digunakan dengan katergori "baik" dengan rerata skor 3,94.

\section{Saran}

Saran dari penelitian pengembangan ini adalah:

1. Media hasil pengembangan produk diharapkan dapat digunakan untuk pembelajaran IPS, agar IPS dibelajarkan secara terpadu sesuai amanat Kurikulum 2006.

2. Perlu dilakukan penelitian pengembangan lebih lanjut terhadap media pembelajaran IPS yang didesain secara terpadu untuk meningkatkan kualitas pembelajaran IPS di SMP dengan tema lain sebagai media dalam pembelajaran IPS.

3. Penelitian pengembangan ini baru sampai pada tahap pengembangan (develop) maka dapat dilakukan penelitian lanjutan hingga tahap penyebarluasan (disseminate) hingga persebaran modul IPS dapat disebarluaskan ke sekolah-sekolah lain. 


\section{Daftar Pustaka}

Depdiknas. 2008. Kamus Besar bahasa Indonesia. Pusat Bahasa. Jakarta: Gramedia Pustaka Utama.

Depdiknas. (2005). Undang-Undang RI Nomor 20 Tahun 2003 tentang Sistem Pendidikan Nasional.

Hariyanto. (2012). Media Pembelajaran. http:/ / belajarpsikologi.com/pengertian-media-pembelajaran/ Diakses pada hari senin tanggal 8 april 2013 pukul 15.06 WIB

Mawardi. (2012). Jenis-jenis Media Pembelajaran. http://coretanpembelajaranku.blogspot.com/2012/10/jenisjenis-media-pembelajaran.html. Diakses pada hari senin tanggal 8 april 2013 pukul 15.10 WIB

Mery Maswarita. (2009). Pemanfaatan Media dan JenisJenis Media.

http://merymaswarita.wordpress.com/2009/11/06/pemanfaa tan-media-dan-jenis-jenis-media/. Diakses hari senin tanggal 8 april 2013 pukul 15.18

Muhammad Numan Somantri. (2001). Menggagas Pembaharuan Pendidikan IPS. Bandung: Remaja Rosdakarya.

Rumampuk, Dientje Borman. (1988). Media Instruksional IPS. Jakarta: Departemen Pendidikan dan Kebudayaan Direktorat Jenderal Pendidikan Tinggi Proyek Pengembangan Lembaga Pendidikan Tenaga Kependidikan.

Sapriya. (2009). Pendidikan IPS. Konsep dan Pembelajaran. Bandung: Remaja Rosda karya.

Savage, Tom V., \& Armstrong, David G. (1996). Effective Teaching in Elementary Social Studies ( $3^{\text {rd }}$ ed.). New Jersey: Prentice-Hall, Inc.

Sekar Purbarini Kawuryan. (Mei 2008). Pentingnya Pendidikan IPS di Sekolah Dasar sebagai Kerangka Dasar Nation and Character Building. Dinamika Pendidikan. Majalah Ilmu Pendidikan, 1, 21-33.

Sofyan, dkk. (2011). Pengembangan Media Audiovisual dalam Pembelajaran Kreatif Menulis Puisi. Diakses dari Online journal.unja.ac.id/index.php/pedagogi/article/view/675 pada hari Kamis tanggal 11 April 2013 Pukul 09.23 WIB.

Tim Pengembang MKDP Kurikulum dan Pembelajaran. (2009). Kurikulum dan Pembelajaran. Bandung: Jurusan Kurtekpen FIP UPI 